\title{
Перспективы укрепления и развития сырьевой базы титанового производства в Восточном Казахстане
}

\author{
М.М. Кравченко ${ }^{a}$, Б.А. Дьячков ${ }^{a, b}$, Е.С. Суйекпаев ${ }^{a}$, \\ Е.М. Сапаргалиев ${ }^{a, b}$, А.Ж. Азельханов ${ }^{a}$, Т.А. Ойцева ${ }^{b}$ \\ a ТОО «Алтайский геолого-экологический институт», Республика Казах- \\ стан, 070004, Усть-Каменогорск, ул. К. Либкнехта, 21 \\ E-mail: suiekpaev@yandex.kz \\ ${ }^{\mathrm{b}}$ Восточно-Казахстанский государственный технический университет \\ им. Д. Серикбаева, Республика Казахстан, 070010, г. Усть-Каменогорск, \\ ул. Серикбаева, 19. E-mail: bdyachkov@ mail.ru \\ (Статья поступила в редакиию 26 ноября 2015 г.)
}

\begin{abstract}
Рассматриваются особенности формирования рудоносных структур Большого Алтая, входящего в систему Центрально-Азиатского подвижного пояса. Подчеркивается генетическая связь первичной циркон-ильменитовой минерализации с постколлизионными интрузивными массивами повышенной щелочности $\left(\mathrm{P}_{2}\right)$, подверженными в мезо-кайнозое преобразованиям в стадию континентального рифтогенеза и стабилизации с образованием остаточных кор выветривания и россыпей ильменита и циркона. Приводится характеристика типовых месторождений, локализованных в Зайсанском прогибе. Выполнена прогнозная оценка территории с обоснованием направлений работ по укреплению сырьевой базы титанового производства.

Ключевые слова: ильменит, изиркон, россыпи, геодинамика, Казахстан.
\end{abstract}

DOI: $10.17072 /$ psu.geol.30.78

Рассматриваемая территория расположена в Восточно-Казахстанской области, в пределах крупной геологической структуры Большого Алтая (БА), входящего в систему Центрально-Азиатского подвижного пояса. Непосредственно БА размещается на северо-западном фланге АлтаеАлашаньской мобильной зоны, огибающей с юга Сибирскую платформу (рис. 1).

В недрах Восточного Казахстана сосредоточены многие месторождения железа, меди, свинца, цинка, золота, редких металлов, титана и других полезных ископаемых. На их базе в регионе создана мощная инфраструктура горнодобывающих и металлургических предприятий и комбинатов, в том числе флаг- ман титанового производства - УстьКаменогорский титано-магниевый комбинат (рис. 2).

Проблема дальнейшего укрепления и развития минерально-сырьевой базы Восточно-Казахстанского региона весьма актуальна. Она усугубляется тем, что фонд легко открываемых месторождений уже исчерпан, оставшихся запасов металлов в недрах хватит на первые десятки лет. Поэтому необходимы открытия новых месторождений цветных, благородных, редких металлов, титанового сырья, редких земель и других металлов.

Важнейшая задача фундаментального плана - это разработка новых теоретических положений в геологии и металлоге-

(c) Кравченко М.М., Дьячков Б.А., Суйекпаев Е.С., Сапаргалиев Е.М., Азельханов А.Ж., Ойцева Т.А., 2016 
нии с целью совершенствования технологии прогнозно-поисковых работ и созда-

ния научной основы восполнения минеральных ресурсов.

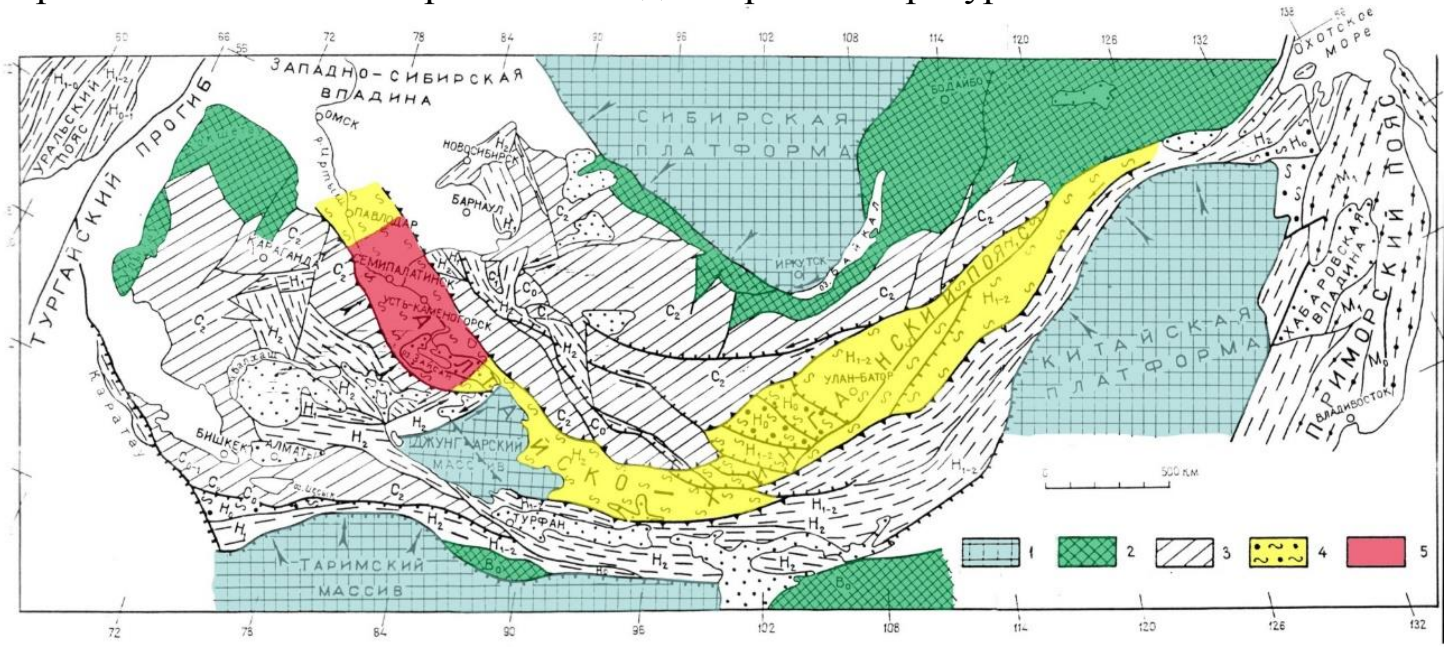

Рис. 1. Геотектоническая позиция Большого Алтая в структурах: 1 - древние платформы и массивы; области: 2 - байкальской и 3 - каледонской складчатости; 4 - Алтае-Алашаньская зона; 5 - положение Большого Алтая

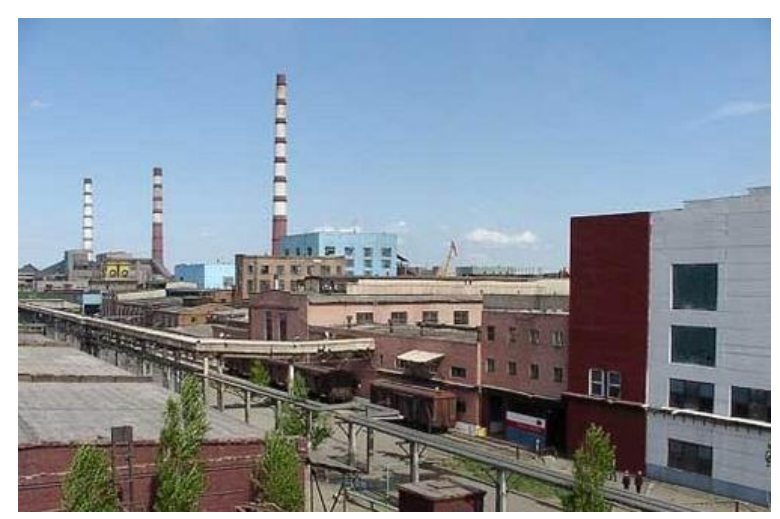

Рис. 2. Общий вид Усть-Каменогорского титано-магниевого комбината

В связи с этим проводимые в последние годы научно-исследовательские работы по общей проблеме «Большой Алтай» (геология и металлогения) с теоретических позиций мобилизма показывают, что в регионе сохраняются перспективы открытия новых месторождений [1]. В результате исследований получен ряд новых представлений о геотектоническом и металлогеническом районировании территории БА по генезису и закономерностям распределения оруденения, зональности рудных поясов и металлогенических зон, геолого-промышленной типизации месторождений и морфоструктурной систематике рудных полей (объектов) и прогноз- но-металлогенической оценке перспектив региона.

С позиций мобилизма предполагается, что геологические структуры БА представляют собой отторженцы древнего палеоконтинента (Восточной Гондваны), которые дрейфовали в Палеоазиатском океане и испытали значительные горизонтальные перемещения с переходом из Южного в Северное полушарие. Большой Алтай как единая целостная структура сформировался в процессе герцинской коллизии (в раннем карбоне и позднее) в результате сдвижения, состыковки и подворота Казахстанской и Сибирской литосферных плит [1-3]. Область сочленения соответствует Зайсанской сутурной зоне, в осевой части которой прослеживается Чарско-Горностаевский офиолитовый пояс и локализовались приразломные малые интрузии, дайки габбро-диорит-гранодиорит-плагиогранитовой серии $\left(\mathrm{C}_{2-3}-\mathrm{C}_{3}\right)$ и многие золоторудные месторождения различных генетических типов [4].

В дальнейшем созданная структура БА усложнялась в позднегерцинскую (постколлизионную) внутриплитную стадию $\left(\mathrm{P}_{2}-\mathrm{T}_{1}\right)$ с мощным развитием гранитоидного магматизма, специализированного на редкометалльное, цирконий-титановое и редкоземельное оруденения. В киммерийский и альпийский циклы континенталь- 
ного рифтогенеза и стабилизации в мезозое-кайнозое образовались месторождения коры выветривания и многие россыпи золота и других металлов. Современная структура Большого Алтая представляется в виде системы ранее разобщенных блоков ЗК, параллельных тектонических зон или коллажа террейнов северо-западного направления (Рудноалтайский, КалбаНарымский, Западно-Калбинский и Жарма-Саурский), разграниченных глубинными разломами и резко различающихся по геодинамическому развитию, геологическому строению и специфике металлогении.

Изучаемая территория расположена в юго-восточной части БА и структурно приурочена к зоне сочленения ЗападноКалбинской и Чарской металлогенических зон в пределах северного борта Зайсанской впадины (рис. 3). В геоморфологическом плане она представлена преимущественно мелкосопочниками и аккумулятивными формами рельефа.

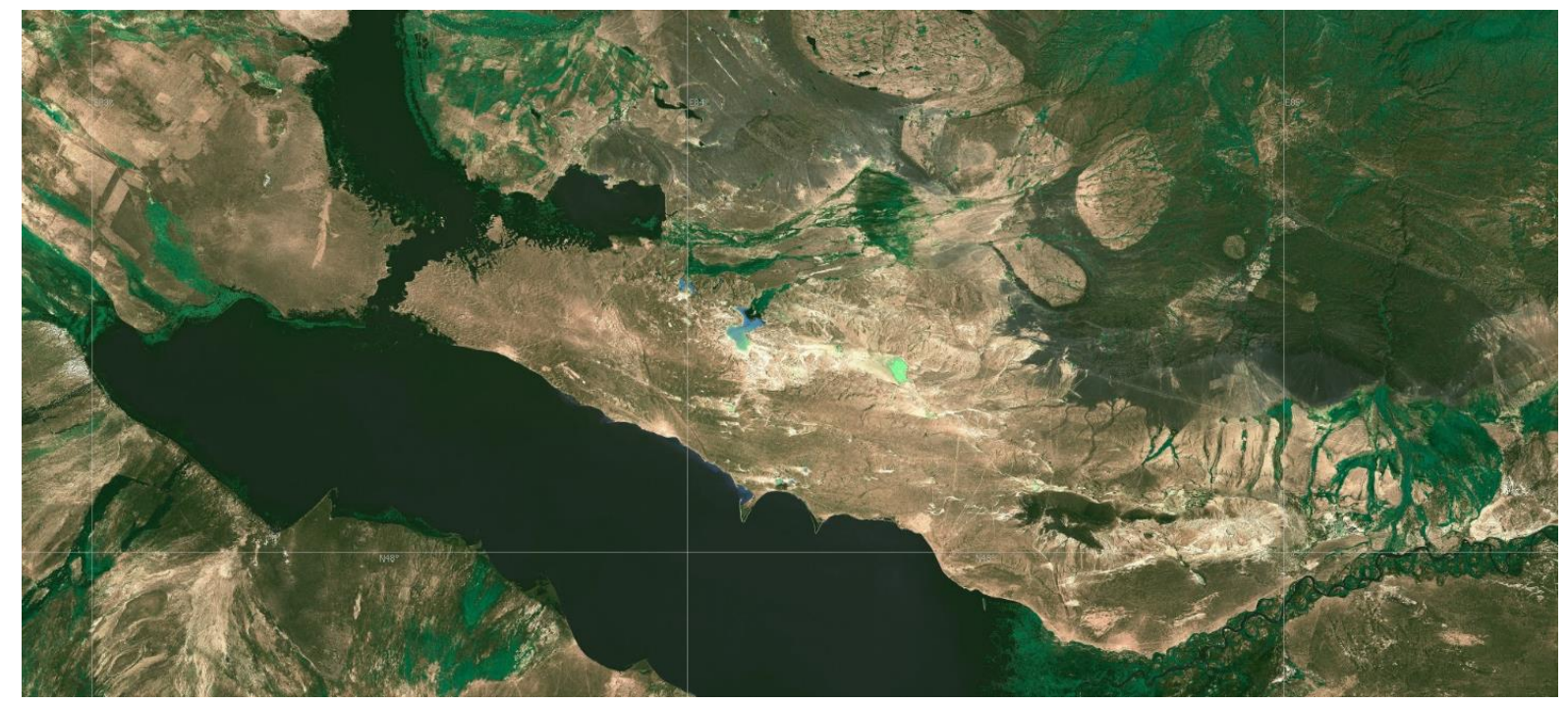

Рис. 3. Схема размещуения района исследования. Космоснимок (Landsat)

Этапы формирования структуры Зайсанского грабена. На перикратонном тафрогенном этапе Т-J (100 млн лет) Зайсанского грабена структура была разбита на фрагментарные блоки, ограниченные северо-западными и широтными разломами, с последующей денудацией и накоплением рыхлого осадочного материала (рис. 4).

Следующий синеклизный этап (мелэоцен - 106 млн лет) характеризовался ослаблением рифтогенеза и перерывами в осадконакоплении, развитием пенеплена и остаточных кор выветривания. Денудация периферии грабена достигла 2,5-3 км мощности, аккумуляция моласс - до 2 км. Основные этапы развития неотектонической структуры.

I. Палеоцен - ранний эоцен, 13 млн лет, - этап слабого оживления тектоники, переотложения меловой коры выветривания в аридном субтропике, образования титан-циркон-кварц-полешпатовой россыпи Караоткель.

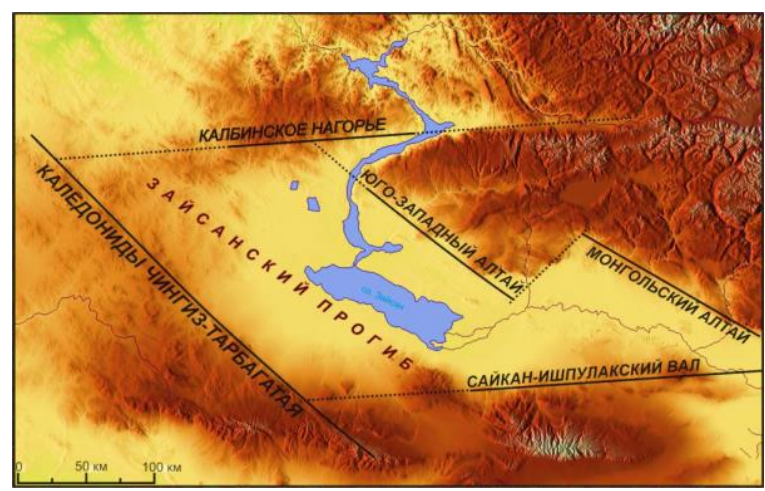

Рис. 4. Геологическая позиция Зайсанского грабена 
II. Эоцен - ранний олигоцен, 20 млн лет, - этап аркогенеза, сводового поднятия на 500-700 м, формирования обновленной гидросети и накопления россыпей ильменита (Сатпаевская и др).

III. Олигоцен - ранний и средний миоцен, 15 млн лет, - этап альпийского рифтогенеза на фоне ускоряющегося сводового поднятия, во второй половине стабилизация, формирование озерной россыпи Жулдыз.

IV. Миоцен - голоцен, 12 млн лет, этап активизации разрывной тектоники, оформления современной структуры гор и образования мелких россыпей в незаконченных циклах.

В процессе эволюции рельефа здесь были созданы благоприятные геоморфологические условия для образования остаточных кор выветривания, их переотложения, формирования погребенных русловых и озерных россыпей ильменита с последующей стабилизацией и накоплением мелких россыпей четвертичного возраста. Ниже приводится краткая характеристика типовых месторождений, размещение которых показано на рис. 5.

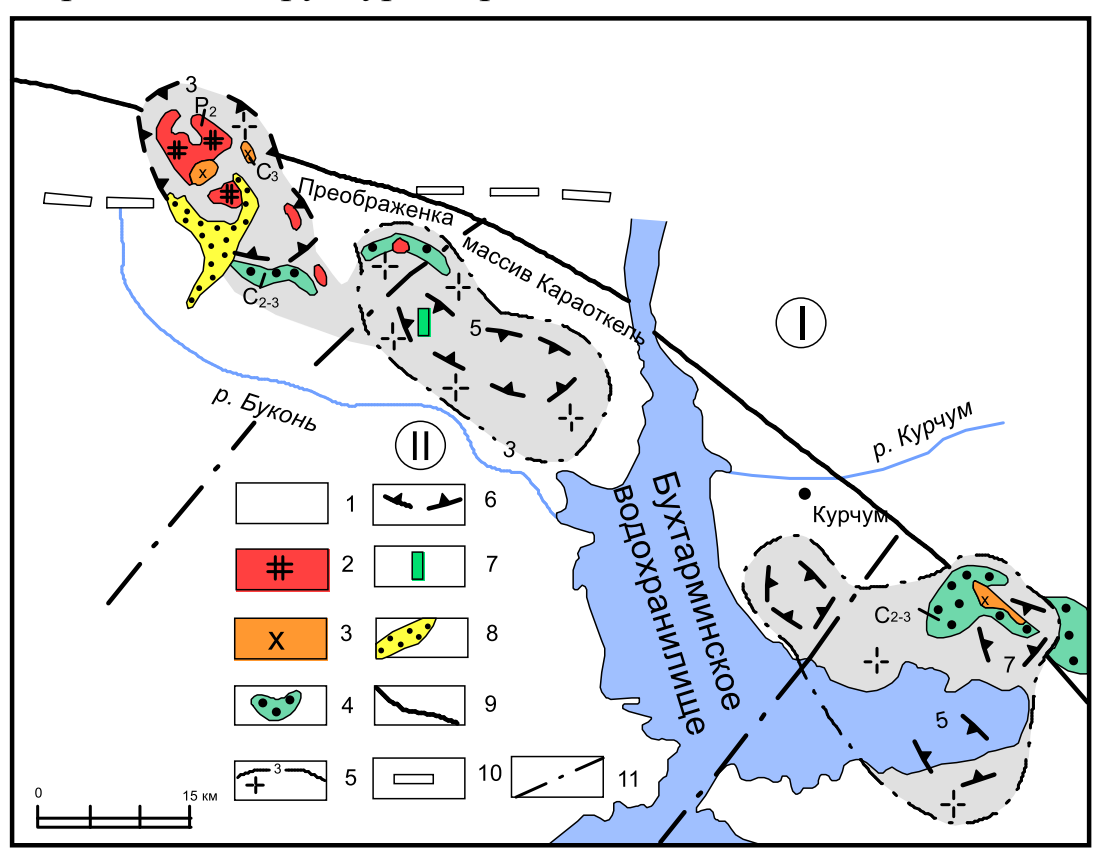

Рис. 5. Схема размещения субщелочных гранитоидных массивов и месторождений в Северном Призайсанье (с учетом геофизических материалов Г.П. Нахтигаля): 1 - рыхлые четвертичные отложения; 2 - субщелочные гранитоиды буранского комплекса $\left(P_{2}\right) ; 3$ - гранитоиды кунушского комплекса $\left(C_{3}\right) ; 4$ - молассы таубинской свиты $\left(C_{2-3}\right) ; 5$ - контуры скрытых гранитоидных массивов, глубина в км; 6 - магмоподводящие корневые утолщения; 7 - ииркон-ильменитполевошпатовое месторождение Караоткель; 8 - ичркон-ильменитовая россыпь Сатпаевская; 9 - граничный глубинный разлом; 10, 11 - разрывные нарушения широтного и северовосточного направления. Римские цифры в кружкках: I - Западно-Калбинская и II - Чарская металлогенические зоны

Месторождение Караоткель представлено корами выветривания каолинового профиля с ильменитом и цирконом, попутными компонентами являются полевые шпаты, кварц, гидрослюды, каолинитовые глины. Сформировалось в киммерийский цикл в рифтогенной геодинамической обстановке в результате выветри- вания интрузивных пород буранского комплекса $\left(\mathrm{P}_{2}\right)$ габбро-монцонит-сиенитщелочно-гранитного состава. Характеризуется линейно-площадной уплощенной морфоструктурой (рис. 6).

На месторождении выделяются два рудоносных горизонта. Первый горизонт представлен первичной корой выветрива- 
ния мощностью 7,4 м (с ильменитом и цирконом). Второй горизонт сложен переотложенной корой выветривания мощностью до 20 м, обогащенной ильменитом a)

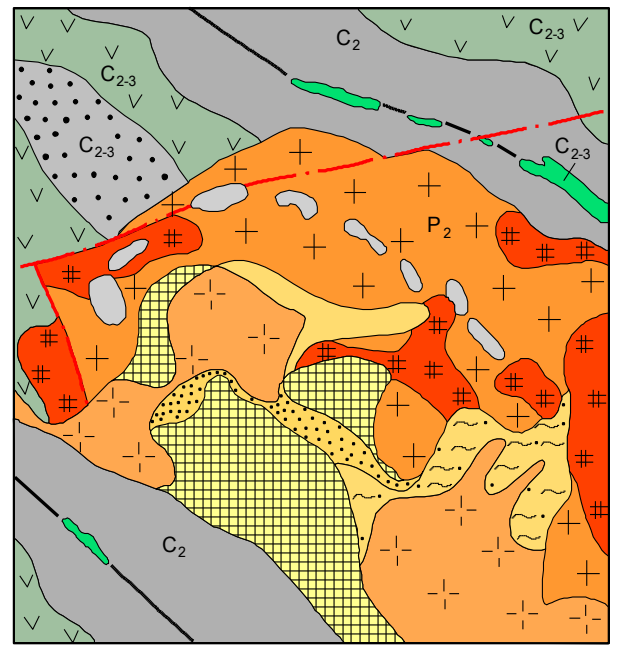

и цирконом. Запасы ильменита подсчитаны по категории $\mathrm{B}+\mathrm{C}_{1}$ (Пахаруков и др., 1991) и составляют 5,9 млн т (среднее со-

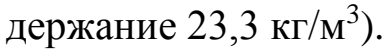
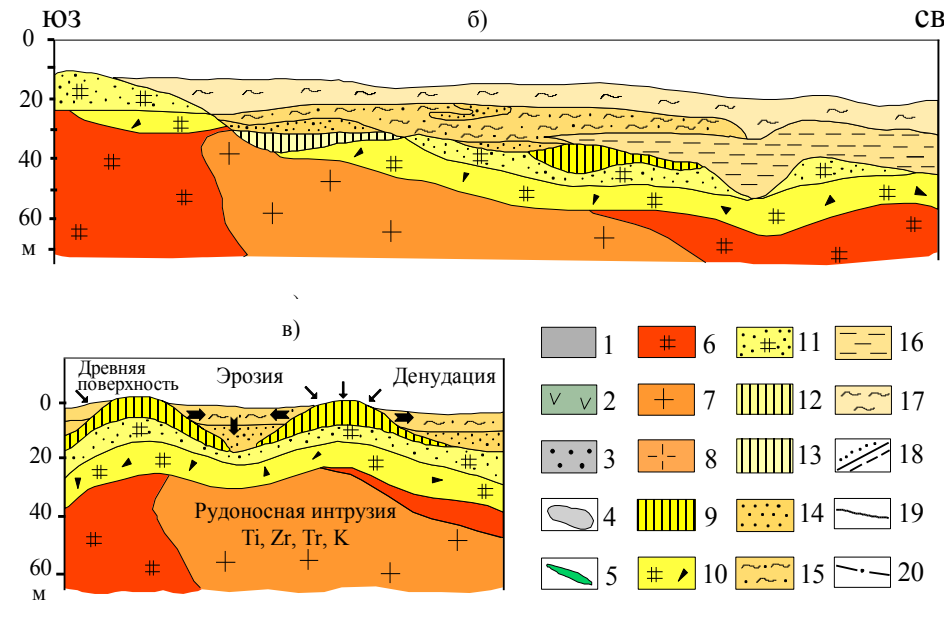

Рис. 6. Схема геологического строения месторождения Караоткель (по материалам М. М. Кравченко, Н. М. Пахарукова): а) план; б) поперечный разрез; в) геолого-генетическая модель; 1 - алевролиты, песчаники, конгломераты буконьской свиты $\left(C_{2}\right) ; 2$ - базальт-андезитовые порфириты даубайской свиты $\left(C_{2-3}\right) ; 3$ - терригенно-молассовые отложения майтюбинской свиты ( $\left.C_{2-3}\right)$; 4 - ксенолиты роговиков; 5 - диабазовые, диоритовые порфириты аргимбайского комплекса (C2-3); 6 - граносиениты, монцониты; 7 - субщелочные граниты буранского комплекса $\left(P_{2}\right) ; 8$ - нерасчлененные гранитоиды под рыхлыми отложениями; 9-11 - коры выветривания: 9 - зона первичных каолинов, 10 - гидрослюд, 11 - структурного элювия; 12 - выходы коры на поверхности, 13 - рудоносные коры с ильменитом и цирконом; 14 - аркозовые пески; 15 - глины с ильменитом и цирконом; 16 - аргиллиты; 17 - глины безрудные северо-зайсанской свиты; 18 - геологические границы (установленные и предполагаемые); 19-20 - геологические границы (установленные и предполагаемые по дешифрированию)

Из ильменита могут быть получены следующие компоненты: $\mathrm{TiO}_{2}-3,2$ млн т (содержание $52,8 \%), \mathrm{Nb}_{2} \mathrm{O}_{5}-576$ т $(0,199$ $\%), \mathrm{Sc}_{2} \mathrm{O}_{3}-270$ т $(0,0045 \%), \mathrm{V}_{2} \mathrm{O}_{5}-2910$ т $(0,047 \%)$. Извлечение ильменита $-86 \%$. Запасы циркона определены в 884 тыс. т (содержание $3,48 \mathrm{\kappa г} / \mathrm{M}^{3}$ ), ожидаемое попутное извлечение $\mathrm{ZrO}_{2}-603600$ т (содержание $66,3 \%), \mathrm{HfO}_{2}-8500$ т $(0,95 \%)$, $\mathrm{YO}_{3}-1790$ т (0,20\%). Извлечение циркона - до 85\%. Месторождение имеет промышленное значение при комплексной разработке на ильменит, циркон, полевой шпат, кварц, минералы редких и редкоземельных элементов.

Сатпаевская ильменитовая россыпь. Обнаружена в 1989 г. при проведении опережающих геофизических и геохимических работ. Характеристика ее приводится по материалам С.Е. Селифонова и Б.М. Шаяхметова с соавторами [8].

Россыпь расположена в юго-западном обрамлении Преображенского гранитоидного массива буранского комплекса. Подчиненное значение имеют габброиды максутского $\left(\mathrm{C}_{2-3}\right)$ и гранитоиды кунушского $\left(\mathrm{C}_{3}\right)$ комплексов. Отмечаются также фрагментарные выходы буконьской $\left(\mathrm{C}_{2}\right)$ и майтюбинской $\left(\mathrm{C}_{2-3}\right)$ свит. Месторождение объединяет три обособленные россыпи, наиболее перспективной является россыпь № 1 (рис. 7).

Ширина русла изменяется от 100 до 650 м, суммарная длина разведанной части россыпи 7250 м, мощность рудных песков от 4 до 11 м. Россыпь по происхождению аллювиальная, продуктивный песчано-глинистый горизонт предполо- 
жительно донеогенового возраста залегает на корах выветривания или на коренных породах. Рудные минералы представлены ильменитом (до 90-97\%) и цирконом, редко встречаются рутил, анатаз и лейкоксен. Среднее содержание ильменита в рудо- носных горизонтах $151 \mathrm{\kappa г} / \mathrm{m}^{3}$. Балансовые запасы россыпи: рудные пески - 12053 тыс. м $^{3}$, ильменит - 1821 тыс. т. В настоящее время россыпь отрабатывается для Усть-Каменогорского титано-магниевого комбината.
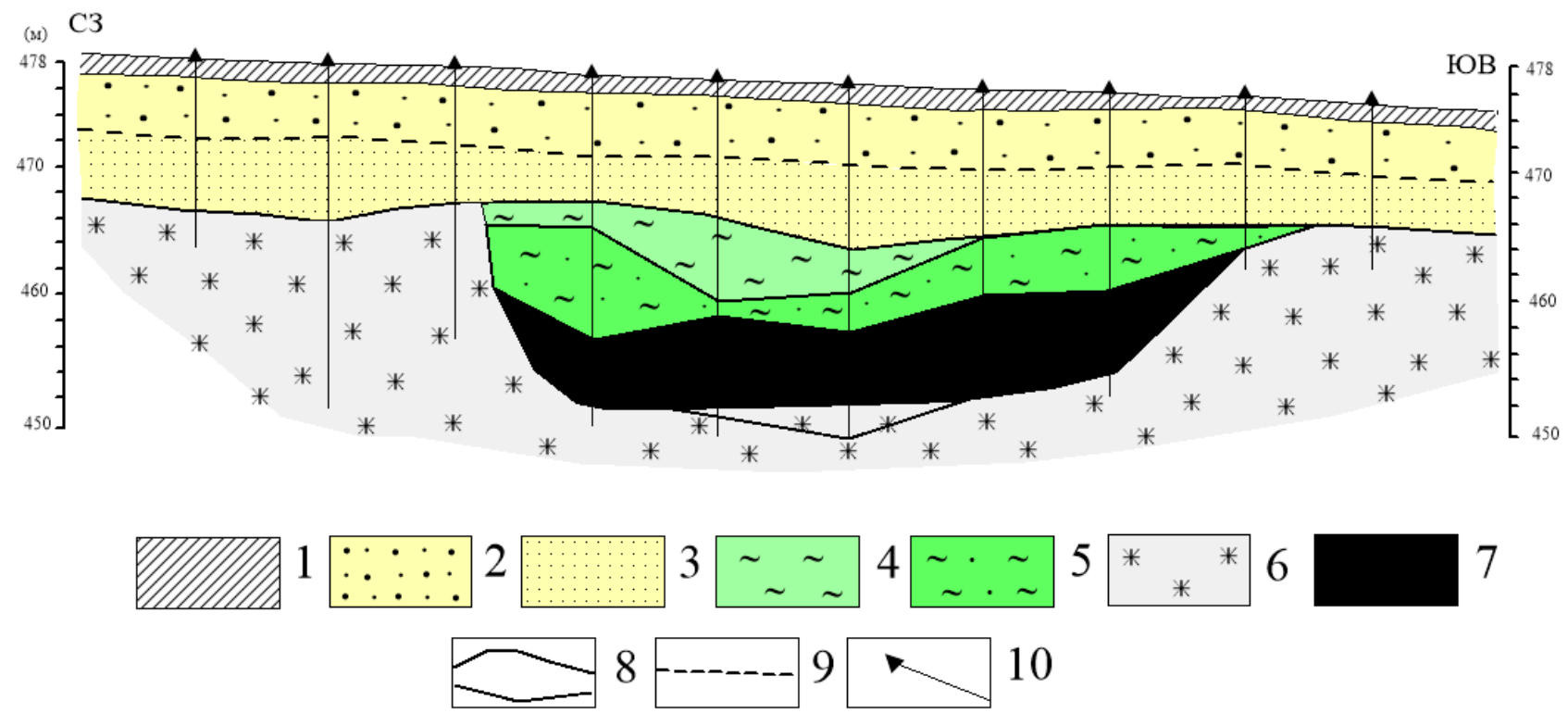

Рис. 7. Сатпаевское месторождение (россыпь №1). Геологический разрез по профилю 58[8]: 1 - четвертичные отложения, суглинки со щебнем $\left(Q_{\text {III-IV }}\right) ; 2$ - песчано-гравийно-галечниковые отложения и 3 - пески $\left(Q_{I}\right) ; 4$ - аральская свита, $N_{l}^{l-2}$, глины ; 5 - песчаные глины, содержсащие некондиционные руды; 6 - коры выветривания по осадочным породам буконьской свиты $\left(C_{2}\right) ; 7$ - балансовые руды;; 8 - контур рудоносной зоны; 9 - статический уровень подземных вод; 10 разведочные скважины

Россыпь ильменита Жулдыз находится в юго-восточном экзоконтакте массива Караоткель. Сформировалась в сарыбулакских слоях павлодарской свиты (средний миоцен), имеет озерное происхождение. Характеризуется наиболее богатым содержанием ильменита (350 $\kappa г / \mathrm{M}^{3}$ ). Россыпь недостаточно изучена, но представляется наиболее перспективной.

В итоге суммарные запасы по всем изученным месторождениям составляют: ильменита $-8,7$ млн т (оксида титана $-4,6$ млн т), циркона - 1,4 млн т (оксида циркония -884 тыс. т). Кроме того, на этих объектах возможно попутное извлечение ниобия, тантала, скандия, ванадия, гафния, церия, что повышает ценность данных месторождений.

Имеющиеся объекты еще не удовлетворяют потребности комбината. Поэтому важнейшая задача заключается в поисках и оценке новых месторождений.

Основные факторы прогноза. Актуальную задачу импортозамещения титанового сырья для казахстанской металлургии можно решить в определенной степени при продолжении геологических исследований с оценкой титаноносности Зайсанского прогиба. Для прогноза перспектив изучаемого региона необходимо учесть следующие факторы.

1. Сложная динамика формирования Зайсанской сутурной зоны сочленения Казахстанской, Сибирской и Джунгарской тектонических плит на этапе поздних герцинид $\left(\mathrm{P}-\mathrm{T}_{1}\right)$, киммерид $\left(\mathrm{T}_{2}-\mathrm{J}_{2}\right)$ и альпийского цикла активизации коромантийных разломов разных направлений дополняется в региональном плане подворотом геологических структур Большого Алтая с широтного и северо-западного направле- 
ния на меридиональное, что согласуется с размещением главных структур Центральной Азии (Мысник, Кравченко, Бочкова, 2003).

2. Рудоконтролирующая роль глубинного разлома северо-западного направления в размещении на границе Западной Калбы и Чарской зоны СемипалатинскоБуран-Бургынского гранитоидного пояса повышенной щелочности, специализированного на циркон-титановое оруденение и другие полезные ископаемые. Пояс имеет значительную протяженность, объединяет группу массивов (Кульский, Дельбегетей, Тастау, Преображенский, Караоткель, Буранский) и на юго-востоке прослеживается в Китай. На большей части территории эти массивы перекрыты чехлом рыхлых отложений и фиксируются по геолого-геофизическим данным и космическим снимкам, благодаря которым установлены кольцевые структуры интрузивных тел.

3. Формирование киммерийскоальпийского рифтогенного Зайсанского грабена с благоприятными геоморфологическими условиями для образования месторождений в остаточных корах выветривания и россыпей.

По результатам исследования на основе геолого-геофизических, минералогогеохимических и дешифровочных признаков выделяются три перспективные площади.

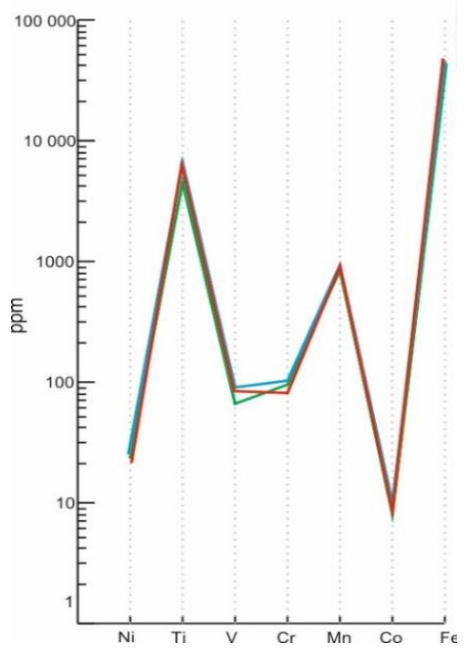

Караоткель-Преображенская площадь $\left(3320 \mathrm{\kappa m}^{2}\right)$ сложена преимущественно габброидами, сиенитами, монцонитами и щелочными гранитами. Их распределение контролируется северо-западными и субширотными разломами. По анализу магнитных аномалий и поля силы тяжести здесь выделяются скрытые габброидные и гранитоидные массивы овальной формы, фрагментарно выходящие на поверхность (Нахтигаль, 1998). Намечены также кольцевые структуры по дешифровочным признакам космических снимков, отражающих скрытые интрузивные тела под маломощным чехлом осадочных пород. На данной площади разведаны цирконильменитовое месторождение Караоткель и россыпь Сатпаевская, а также прогнозируется перспективная россыпь Жулдыз.

Авторами проводилось дополнительное изучение вещественного состава рыхлых отложений с использованием электронной микроскопии. В составе серого шлиха пробы, отобранной с поверхности, по данным масс-спектрометрии (ICP MS) выявлены повышенные содержания (г/т) таких элементов, как Тi (6 413), Zr (189), Y $(31,62)$ и редкие земли $(76,2)$ (рис. 8), среди которых преобладает легкая подгруппа лантаноидов ( $\mathrm{La}, \mathrm{Ce}, \mathrm{Pr}$ и др.).

Рис. 8. Содержание сидерофильных и рассеянных элементов в шлихах 
Как видно, лабораторные исследования подтверждают зараженность рыхлого чехла Ti, Zr и редкими землями. На выделенной перспективной площади в первую очередь рекомендуется постановка глубинного геологического картирования с привлечением значительных объемов геофизических, минералого-геохимических и буровых работ.

Курчум-Кальджирская площадь $\left(2270\right.$ км $\left.^{2}\right)$ прогнозируется на основе данных геофизических исследований и дешифрировочных признаков, по которым здесь выделяются кольцевые структуры на поверхности и предполагаются на глубине предыдущими исследователями. В этом районе установлены проявления титаносодержащей коры выветривания и россыпей ильменита, циркона, касситерита и шеелита. На этом основании площадь также представляется перспективной и заслуживает дальнейшего изучения.

Буранская площадь $\left(1600 \mathrm{км}^{2}\right)$ подчеркивается кольцевой структурой, сложенной интрузивными породами монцонит-сиенит-щелочно-гранитного состава (буранский комплекс). Выходы интрузивных пород Буранского массива обнажаются фрагментарно, а большая его часть перекрыта рыхлыми отложениями (рис. 10).

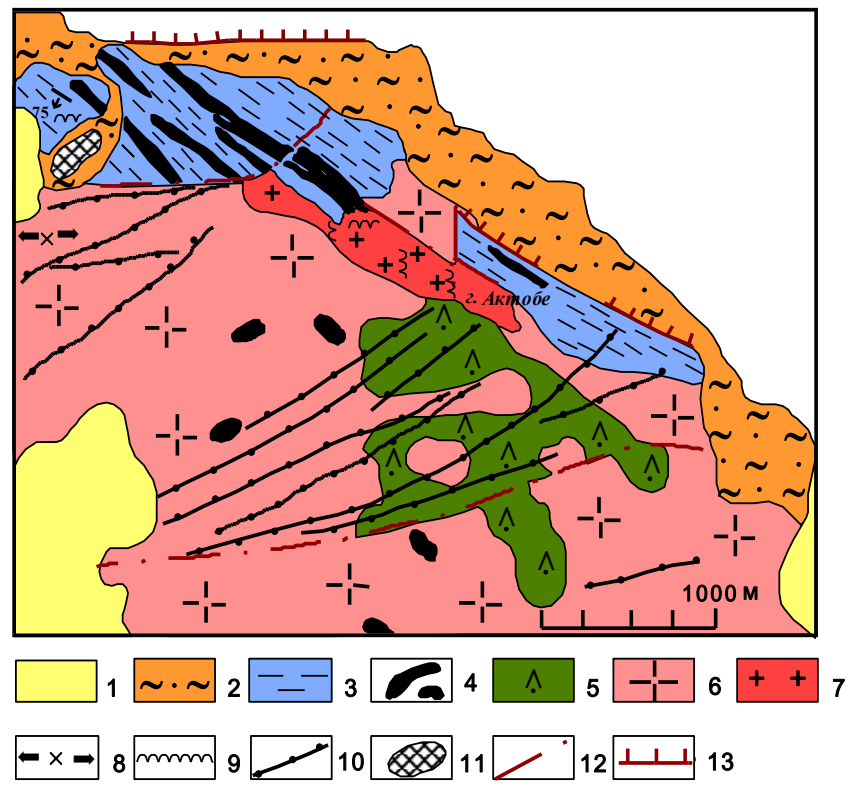

Рис. 10. Геологическое строение Буранского массива (Северное Призайсанье): 1 - рыхлые четвертичные отложения; 2 - пестрочветные глины, алевролиты, пески, галечники, конгломератыл северо-зайсанской свиты $\left(K_{2}-P_{2}^{2}\right) ; 3$ - песчаники с прослоями углисто-глинистых алевролитов аганактинской свиты ( $C_{I} s$ ?); 4 - метаморфизованные дайки плагиогранит-порфиров, гранит-порфиров кунушского комплекса $\left(C_{3}\right)$ и их реликты в более поздних сиенитах; 5 - среднекрупнозернистые биотит-роговообманковые сиениты I фазы, 6 - среднезернистые роговообманковые сиениты II фазы и 7 -мелкозернистые роговообманково-биотитовые субщелочные граниты, граносиениты III фазы буранского комплекса $\left(P_{2}\right) ; 8$-жильные аплит-пегматиты, 9 - квариевые жилы; 10 - гранит-порфиры, квариевые порфиры бугазского комплекса $\left(P_{2}-T_{1}\right) ; 11$ - железисто-кремнистые образования коры выветривания; 12 - разрывные нарушения; 13 те же, активизированные в альпийское время

По результатам предыдущих работ интрузивные образования буранского комплекса характеризуются акцессорной и геохимической $\mathrm{Zr}$-Ti специализацией. Массив перекрыт рыхлыми отложениями незначительной мощности, возможно обнаружение погребенных кор выветривания и россыпей ильменита и циркона. Целесообразна постановка глубинного геологического картирования. 


\section{Выводы}

На основе региональных геологогеофизических материалов дешифрирования космоснимков и детальных исследований уточнена геотектоническая позиция и рудоносность Семипалатинско-БуранБургынского пояса гранитоидов повышенной щелочности, сформированного в постколлизионной геодинамической обстановке $\left(\mathrm{P}_{2}-\mathrm{T}_{1}\right)$ в области сочленения Казахстанской и Сибирской литосферных плит. Определена генетическая связь первичного циркон-титанового оруденения с интрузивными массивами габбромонцонит-сиенит-щелочно-гранитного состава (буранский комплекс $\mathrm{P}_{2}$ и его аналоги), преобразование которых в киммерийский цикл континентального рифтогенеза и процессе альпийской стабилизации сопровождалось формированием цирконильменитовых остаточных кор выветривания (месторождение Караоткель) и россыпей руслового (Сатпаевская) и озерного (Жулдыз) типов.

Намечена этапность формирования киммерийско-альпийского Зайсанского грабенообразного прогиба и выделены возрастные рубежи тектоноденудационных циклов формирования ильменит-циркон-редкоземельных кор выветривания и россыпей совмещенного типа и ближнего сноса: отложения северозайсанской свиты К $\mathrm{K}_{2} \mathrm{E}_{1}$ (коры выветривания и аллювиальная россыпь Караоткель); аллювиально-пролювиальные отложения олигоцена $\mathrm{E}_{3}$ (россыпь Сатпаевская); озерные отложения сарыбулакской свиты неогена $\mathrm{N}_{1}$ (россыпь Жулдыз).

Выполнена прогнозная оценка ресурсов титанового сырья на изучаемой территории (ильменита 5 млн т, $\mathrm{TiO}_{2} 3$ млн т) с возможным попутным извлечением циркона, минералов редких и редкоземельных элементов. Реализация прогнозов при постановке соответствующих научноисследовательских и геологоразведочных работ будет способствовать импортоза- мещению минерального сырья для титанового производства в Республике Казахстан.

\section{Библиографический список}

1. Берзин Н. А., Колман Р. К., Добрецов Н. Л. и $\partial p$. Геодинамическая карта западной части Палеоазиатского океана // Геология и геофизика. 1994. Т.35, №7-8. С.8-28.

2. Большой Алтай (геология и металлогения). Алматы: Гылым, 1998. Кн. 1. 304 с.; 2000. Кн. 2. 400c.

3. Владимиров А.Г., Крук Н.Н., Хромых С.В. и $\partial p$. Пермский магматизм и деформации литосферы Алтая как следствие термических процессов в коре и мантии // Геология и геофизика. 2008. Т. 49, №7. С. 621636.

4. Дьячков Б.А., Кузьмина О.Н., Зимановская H.A. и др. Типы золоторудных месторождений Восточного Казахстана. УстьКаменогорск, 2015. 150 с.

5. Дьячков Б.А., Черненко 3.И., Матайбаева И.Е., Фролова О.В., Суйекпаев Е.С. Геологическое строение и полезные ископаемые Буранского участка (Северное Призайсанье) // Зап. Усть-Каменогор. казахстан. географ. об-ва / Вост.-Казахстан. гос. техн. ун-т. Усть-Каменогорск, 2015. С. 94 104.

6. Дьячков Б.А., Мочалкина Л.Н., Кузьмина О.Н., Бочкова О.И., Кравченко М.М. Типы месторождений кор выветривания Восточного Казахстана // Вестник ВКГТУ. 2005. №4. C. 6-12.

7. Кравченко М.М., Суйекпаев Е.С., Сапаргалиев Е.М., Дьячков Б.А., Азельханов А.Ж. Перспективы укрепления минеральносырьевой базы титанового производства в Восточном Казахстане // Матер. Междунар. совещ. по геологии россыпей и месторождений кор выветривания (24-28 августа 2015 г.) / Перм. гос. нац. исслед. унт. Пермь, 2015. С. 113-114.

8. Минерально-сырьевые ресурсы Восточного Казахстана и их комплексное использование. Усть-Каменогорск, 1999. 169с. 


\section{Prospects of Strengthening and Development of the Titanium Production Resource Base in Eastern Ka- zakhstan}

M.M. Kravchenko a, B.A. Dyachkov ${ }^{a, b}$, E.S. Suyekpaev ${ }^{a}$, E.M. Sapargaliev ${ }^{a, b}$, A.Zh. Azelkhanov ${ }^{a}$, T.A. Oytseva ${ }^{\text {b }}$

${ }^{a}$ Altay Geology and Ecology Institute, 21 K. Libknekht Str., Ust-Kamenogorsk

070004, Kazakhstan Republic, E-mail: suiekpaev@yandex.kz

${ }^{\mathrm{b}}$ East-Kazakhstan State Technical University, 19 D. Serikbaeva Str., Ust-

Kamenogorsk 070010, Kazakhstan Republic, E-mail: bdyachkov@mail.ru

In the article, the aspects of metalliferous structures of the Great Altay, incorporated in system of the Central_Asian mobile belt, are presented. This work considers the genetic relation of the primary zirconium-ilmenite mineralization to the post-collision intrusive alkaline massifs $\left(\mathrm{P}_{2}\right)$, experienced the transformation at the continental riftogenesis stage in Mezo-Cenozoic, and further stabilization accompanied by formation of residual weathering crusts with zircon-ilmenite placers. Characteristics of the typical deposits, located in the Zaysan Depression, are presented as well. The forecast evaluation of territory and feasibility study of further work on the strengthening of Titanium production resource base were conducted.

Key words: ilmenite, zircon, placers, geodynamics, Kazakhstan.

\section{References}

1. Berzin N.A., Kolman R.K., Dobretsov N.L. et al. 1994. Geodinamicheskaya karta zapadnoy chasti Paleoaziatskogo okeana [Geodynamic map of the western part of Paleo-Asian Ocean]. Geologiya i geofizika. 35(7-8);8-28. (in Russian)

2. Bolshoy Altay (geologiya i metallogeniya) [Great Altay (geology and metallogenesis)]. T. 1, Almaty, Gylym, 1998, p. 304; T. 2, RIO VAK RK, 2000, p. 400. (in Russian)

3. Vladimirov A.G., Kruk N.N., Khromykh S.V. et al. 2008. Permskiy magmatism I deformatsii litosfery Altaya kak sledstvie termicheskikh protsessov v kore i mantii [Permian magmatism and deformations of the Altay lithosphere as consequence of thermal processes in crust and mantle]. Geologiya i geofizika. 49(7): 621-636. (in Russian)

4. Dyachkov B.A., Kuzmina O.N., Zimanovskaya N.A. et al. 2015. Tipy zolotorudnykh mestorozhdeniy Vostochnogo Kazakhstana [Types of gold deposits of the East Kazakhstan]. Ust-Kamenogorsk, VKGTU, p. 150. (in Russian)

5. Dyachkov B.A., Chernenko Z.I., Mataybaeva I.E., Frolova O.V., Suyekpaev E.S. 2015. Geo- logicheskoe stroenie i poleznye iskopaemye Buranskogo uchastka (Severnoe Prizaysanie) [Geological setting and mineralization of Buranskiy area (Northern PriZaysanie)]. In Zapiski Ust-Kamenogorskogo Kazakhskogo geograficheskogo obshchestva, pp. 94-104. (in Russian)

6. Dyachkov B.A., Mochalkina L.N., Kuzmina O.V., Bochkova O.I., Kravchenko M.M. 2005. Tipy mestorozhdeniy kor vyvetrivaniya Vostochnogo Kazakhstana [Types of weathering crust deposits of the Eastern Kazakhstan]. Vestnik BKGTU. 4:6-12. (in Russian)

7. Kravchenko M.M., Suyekpaev E.S., Sapargaliev E.M., Dyachkov B.A., Azelkhanov A.Zh. 2015. Perspektivy ukrepleniya mineralnosyryevoy basy titanovogo proizvodstva v Vostochnom Kazakhstane [Prospects of strengthening the mineral resources base for the Titanium production in Eastern Kazakhstan]. Mat. Int. Meeting on geology of placers and deposits in weathering crusts. August 24-28, 2015, Perm, PSU, pp. 113-114. (in Russian)

8. Mineralno-syryevye resursy Vostochnogo Kazakhstana i ikh kompleksnoe ispolzovanie [Mineral resources of the East Kazakhstan and their complex development]. Ust-Kamenogorsk, 1999, p. 169. (in Russian) 